\title{
Polymorphisms in the LPL gene and their association with growth traits in Jiaxian cattle
}

\author{
L.S. Gui ${ }^{1 *}$, Y.M. Huang ${ }^{1 *}$, J.Y. Hong ${ }^{1}$ and L.S. Zan $^{1,2}$ \\ ${ }^{1}$ College of Animal Science and Technology, Northwest A\&F University, \\ Yangling, Shaanxi, China \\ ${ }^{2}$ National Beef Cattle Improvement Center of Northwest A\&F University, \\ Yangling, Shaanxi, China \\ *These authors contributed equally to this study. \\ Corresponding author: L.S. Zan \\ E-mail: zanlinsen@163.com
}

Genet. Mol. Res. 15 (2): gmr. 15027590

Received September 4, 2015

Accepted December 2, 2015

Published April 26, 2016

DOI http://dx.doi.org/10.4238/gmr. 15027590

ABSTRACT. Previous studies showed that the lipoprotein lipase (LPL) gene was involved in metabolism and transport of lipids, suggesting that the LPL is a potential candidate gene affecting growth traits in animals. The aim of this study was to identify polymorphism in the bovine LPL gene and analyze its possible association with growth traits in 218 randomly selected Jiaxian cattle. We used DNA sequencing to identify single nucleotide polymorphisms (SNPs) in the LPL gene. A sequence analysis revealed three SNPs: two in intron 5 (C18306T and C18341T) and one in exon 6 (G18362A). G18362A is a missense mutation leading to a change of the 325 th glycine to serine. Based on $\chi^{2}$ tests, the genotypic distributions of C18306T were in agreement with the Hardy-Weinberg equilibrium $(\mathrm{P}>0.05)$, whereas the other two mutations were not $(0.05>\mathrm{P}>0.01)$. Association analyses showed that the C18341T SNP was significantly associated with several growth traits $(\mathrm{P}<0.01$ or $\mathrm{P}<0.05)$, and the G18362A was associated with withers height $(\mathrm{P}<0.05)$. Our results suggest that 
LPL gene variation may be considered molecular markers for growth traits in Jiaxian cattle.

Key words: Growth traits; Jiaxian cattle; Lipoprotein lipase

\section{INTRODUCTION}

The LPL gene plays an important role in the metabolism and transport of lipids as an enzyme. It is responsible for hydrolysis of the triglyceride (TG) component in circulating chylomicrons (CMs) and very low-density lipoprotein (VLDL) via binding to apolipoprotein C2 (Kolovou et al., 2005). Several studies have confirmed linkage and association of the LPL gene with hypertension (Muñoz-Barrios et al., 2012), obesity (McQuaid et al., 2011), and insulin resistance (Goodarzi et al., 2004) for the features of the insulin resistance or metabolic syndrome. For example, overexpression of the LPL gene in skeletal muscles led to excessive intramyocellular lipid deposition, suggestive of the relationship between lipid storage and insulin sensitivity (Kim et al., 2001). In turn, a deficiency of the LPL gene in 3T3-L1 cells resulted in a reduction of intracellular lipid levels, which suggests that the adipocyte-derived LPL gene is required for efficient fatty acid uptake and storage (Gonzales and Orlando, 2007). Research on the function of the LPL gene has suggested an important role in energy balance regulation. Substantial evidence suggests that TG-rich lipoproteins were detected in the brain using an LPL-dependent mechanism, and provided lipid signals for the central regulation of body weight and energy balance in mice (Wang et al., 2011).

The bovine LPL gene maps to chromosome 8 and its coding region consists of 10 exons, which are highly expressed in skeletal muscle and adipose tissue (Holmes et al., 2011). Wang et al. (2012) identified two polymorphisms (T355420C and A355427T) of the LPL gene that were associated with growth traits in Xiangxi cattle. Oh et al. (2013) confirmed three novel SNPs (G322A, A329T, and G1591A) in the bovine LPL gene, which can affect fatty acid composition and carcass traits in Korean cattle. Additionally, in yak (Bos grunniens), the C19913T variation is associated with average daily gain and carcass weight (Ding et al., 2012). Taken together, these findings lend credence to the hypothesis that the LPL gene is an excellent candidate gene for growth-related traits in livestock.

So far, no study has examined the association between SNPs and growth traits in general. Therefore, the present study was performed to identify SNPs in the LPL gene of Jiaxian cattle and to evaluate the association of these polymorphisms with growth traits.

\section{MATERIAL AND METHODS}

\section{DNA sample preparation and data collection}

DNA samples were obtained from jugular blood from 218 adult (3-5 years old) Jiaxian cattle from the Jiaxian cattle-breeding farm (Jiaxian County, Henan Province). The studied animals were selected to be unrelated for at least three generations. DNA extraction was performed using a standard phenol-chloroform method (Müllenbach et al., 1989).

The growth traits, including withers height, body length, chest depth, and hip width, were measured as previously described (Gilbert et al., 1993). To minimize systematic error, a single person was assigned to measure all ten traits in all animals. 


\section{Variant discovery}

According to the sequence of the bovine LPL gene (NM_001075120.1), a primer A (sense: 5'-CTTAAACAGGACCTACGATC-3', anti-sense: 5'-CCTTACTAGCAGTGGGAAT-3') was designed to amplify a 585-bp fragment of the LPL gene in exon 6 using the Primer 5 software (Gui et al., 2015).

The 20- $\mu \mathrm{L}$ polymerase chain reaction (PCR) reaction mixture contained 50 ng genomic DNA, $10 \mathrm{pM}$ each primer, $0.20 \mathrm{mM}$ dNTPs, $2.5 \mathrm{mM} \mathrm{MgCl}_{2}$, and $0.5 \mathrm{U}$ Taq polymerase (TaKaRa, Dalian, China). The PCR conditions were: $95^{\circ} \mathrm{C}$ for $5 \mathrm{~min}$ (preliminary denaturation), 35 cycles at $94^{\circ} \mathrm{C}$ for $30 \mathrm{~s}$ (denaturation), $30 \mathrm{~s}$ at $62.5^{\circ} \mathrm{C}$ annealing (temperature specific for a single analyzed fragment), and $72^{\circ} \mathrm{C}$ for $40 \mathrm{~s}$ (extension). The final extension was performed at $72^{\circ} \mathrm{C}$ for $10 \mathrm{~min}$.

The products for sequencing were first electrophoresed on $2.0 \%$ agarose gels, then purified using Axygen kits (BMI Fermentas, Glen Burnie, MD, USA), and finally sequenced in both directions in an ABI PRIZM 377 DNA sequencer (Perkin-Elmer, Dalian, China). The sequence maps were analyzed with the SeqMan software 13.0 (Swindell and Plasterer, 1997). DNA sequencing revealed three mutations (C18306T, C18341T, and G18362A).

\section{Statistical analysis}

Gene frequencies and allelic frequencies were determined by direct counting. HardyWeinberg equilibrium (HWE) gene heterozygosity $\left(H_{\mathrm{E}}\right)$, gene homozygosity $\left(H_{\mathrm{O}}\right)$, and effective allele numbers $\left(N_{\mathrm{E}}\right)$ were statistically analyzed following the approach by Nei and Roychoudhury (1974). The polymorphism information content (PIC) was calculated according to Botstein et al.'s (1980) methods.

The associations between SNPs and ultrasound carcass traits in Jianxian cattle were analyzed using general linear models (GLM) in SPSS v. 13.0. The following statistical linear model was used: $\mathrm{Y}_{\mathrm{i}}=\mu+$ Marker $_{\mathrm{i}}+\mathrm{e}_{\mathrm{i}}$; where $Y_{i}$ are the traits measured on each of the individual animals; $\mu$ is the overall population mean for the trait, Marker ${ }_{i}$ is the effect of maker genotype, and $e_{i}$ is the residual effect.

\section{RESULTS}

\section{Genetic polymorphism of the Jiaxian cattle LPL gene and $\chi^{2}$ tests}

Sequence analysis of the LPL gene revealed three mutations: $\mathrm{C}>\mathrm{T}$ mutation at 18,306 bp, C $>$ T mutation at 18,341 bp, and G>A mutation at 18,362 bp, named C18306T, C18341T, and G18362A, respectively (Figure 1). G18362A, a missense mutation leading to the change of the 325th glycine to serine, was in the coding region, whereas the other two mutations were all in intron 5 of the bovine LPL gene.

The allelic and genotypic frequencies, and the genetic diversity parameters $\left(H_{\mathrm{E}}, N_{\mathrm{E}}\right.$, and PIC) for the SNPs are summarized in Table 1. At the C18306T locus, the mutant allele (CT) was less frequent than the wild allele (CC); the allele frequencies, $H_{\mathrm{E}}$ and $N_{\mathrm{E}}$ were as follows: $0.642(\mathrm{C}), 0.358(\mathrm{~T}), 0.460$, and 1.850 . For the $\mathrm{C} 18341 \mathrm{~T}$ mutation, the results showed that CC was the most prevalent genotype (49.60\%) followed by CT (33.00\%) and 
TT (17.40\%). The allele frequencies, $H_{\mathrm{E}}$, and $N_{\mathrm{E}}$ at this locus were $0.661(\mathrm{C}), 0.339(\mathrm{~T})$, 0.448 , and 1.813 , respectively. In addition, for the G18362A mutation, the GG $(0.119)$ and GA (0.239) genotypes were less frequent than the AA (0.642) genotype. The allele frequencies, $H_{\mathrm{E}}$, and $N_{\mathrm{E}}$ at this locus were $0.238(\mathrm{G}), 0.762(\mathrm{~A}), 0.363$, and 1.571 .

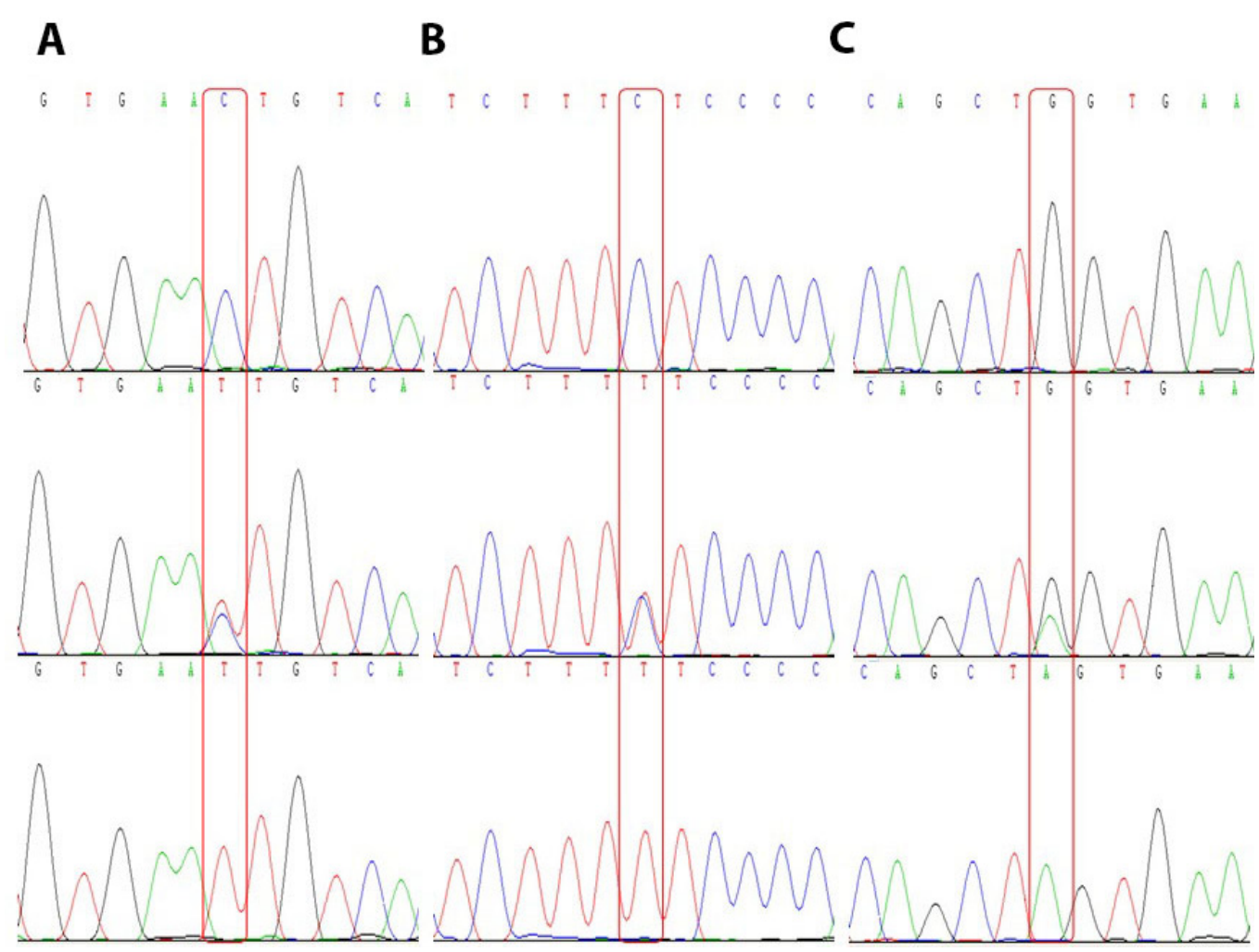

Figure 1. Sequencing maps of loci SNP18306 (A), SNP18341 (B), and SNP18362 (C).

Table 1. Genotype frequencies (\%) of the LPL gene for SNPs in a Jiaxian cattle population.

\begin{tabular}{|c|c|c|c|c|c|c|c|c|c|c|}
\hline Locus & \multicolumn{3}{|c|}{ Genotype frequencies } & Total & \multicolumn{2}{|c|}{ Allelic frequencies } & \multirow[t]{2}{*}{$\operatorname{HWE}\left(\chi^{2}\right)$} & \multirow[t]{2}{*}{ PIC } & \multirow[t]{2}{*}{ Gene heterozygosity $\left(H_{\mathrm{E}}\right)$} & \multirow[t]{2}{*}{ Effective allele numbers $\left(N_{\mathrm{E}}\right)$} \\
\hline \multirow{2}{*}{ C18306T } & $\mathrm{CC}$ & CT & TT & \multirow[t]{2}{*}{218} & $\mathrm{C}$ & $\mathrm{T}$ & & & & \\
\hline & 0.436 & 0.413 & 0.151 & & 0.642 & 0.358 & 2.252 & 0.354 & 0.460 & 1.850 \\
\hline \multirow[t]{2}{*}{$\mathrm{C} 18341 \mathrm{~T}$} & $\mathrm{CC}$ & CT & TT & \multirow[t]{2}{*}{218} & $\mathrm{C}$ & $\mathrm{T}$ & & & & \\
\hline & 0.496 & 0.330 & 0.174 & & 0.661 & 0.339 & 15.138 & 0.348 & 0.448 & 1.813 \\
\hline \multirow[t]{2}{*}{ G18362A } & GG & GA & $\mathrm{AA}$ & \multirow[t]{2}{*}{218} & $\mathrm{G}$ & A & & & & \\
\hline & 0.119 & 0.239 & 0.642 & & 0.238 & 0.762 & 25.703 & 0.297 & 0.363 & 1.571 \\
\hline
\end{tabular}

$\mathrm{HWE}=$ Hardy-Weinberg equilibrium; $\chi_{0.05}^{2} \geq 5.991, \mathrm{P} \leq 0.05 ; \chi_{0.01}^{2} \geq 9.210, \mathrm{P} \leq 0.01$.

Moreover, the $\chi^{2}$ test showed that C18306T was in $\operatorname{HWE}\left(\chi^{2}=2.252, \mathrm{P}>0.05\right)$, whereas the individual genotypic frequencies were deviating strongly from HWE for the other SNPs $\left(\chi^{2}=15.138, \mathrm{P}<0.05\right.$, and $\chi^{2}=25.703, \mathrm{P}<0.05$, respectively). Probable explanations may be that the sample size was limited in our study, that Jiaxian cattle have experienced strong selection pressure, or that artificial selection eventually has led to the loss of certain alleles except the favored ones (Huang et al., 2013). 
In order to measure the in formativeness of the identified SNPs, PIC was calculated for each locus. The PIC values ranged from 0.297 to 0.354 . The convention for classification of PIC dictates that a PIC value less than 0.250 indicates low polymorphism, a value from 0.250 to 0.500 indicates intermediate polymorphism, and a value greater than 0.500 indicates high polymorphism (Xue et al., 2013). Our results indicated that all three SNPs exhibited intermediate genetic diversity.

\section{Analysis of the association of the polymorphisms with growth traits}

In the present study, we detected three SNPs in the LPL and analyzed their association with economically relevant growth traits in 218 Jiaxian cattle. The association analysis between each marker and the growth traits are shown in Table 2. The results showed that there were no statistically significant associations between the C18306T and any of the studied traits $(\mathrm{P}>0.05)$. Individuals with genotype $\mathrm{C} 18341 \mathrm{~T}-\mathrm{TT}$ had increased withers height, body length, and chest depth compared with the C18341T-CC genotype $(\mathrm{P}<0.01)$. Statistically significant differences were also found between the C18341T-TT and C18341T-CT genotypes in body length and hip width $(\mathrm{P}<0.05)$, demonstrating that the C18341T-T allele might be beneficial to breed cattle with superior withers height, body length, chest depth, and hip width. At the G18362A locus, the results showed that animals with the G18362A-GA genotype had significantly greater withers height compared to those with the G18362A-AA genotype (P $<0.05)$, demonstrating that the G18362A-G allele might also be associated with increased withers height.

Table 2. Association between the different SNPs in the LPL gene and growth traits in Jiaxian cattle.

\begin{tabular}{|c|c|c|c|c|}
\hline \multirow[t]{2}{*}{ Locus } & \multirow[t]{2}{*}{ Traits $(\mathrm{cm})$} & \multicolumn{3}{|c|}{ Genotypes } \\
\hline & & $\mathrm{CC}$ & CT & TT \\
\hline \multirow[t]{4}{*}{ C18306T } & Withers height & $125.347 \pm 0.683$ & $125.689 \pm 0.702$ & $124.848 \pm 1.159$ \\
\hline & Body length & $141.305 \pm 0.956$ & $141.678 \pm 0.982$ & $142.970 \pm 1.621$ \\
\hline & Chest depth & $172.084 \pm 1.755$ & $173.933 \pm 1.804$ & $169.212 \pm 2.979$ \\
\hline & Hip width & $41.347 \pm 0.280$ & $41.867 \pm 0.287$ & $41.545 \pm 0.474$ \\
\hline \multirow[t]{5}{*}{$\mathrm{C} 18341 \mathrm{~T}$} & & $\mathrm{CC}$ & CT & TT \\
\hline & Withers height & $123.278 \pm 0.590^{B}$ & $125.986 \pm 0.723^{\mathrm{B}}$ & $130.395 \pm 0.995^{\mathrm{Aa}}$ \\
\hline & Body length & $140.065 \pm 0868^{B}$ & $141.569 \pm 1.063^{b}$ & $146.658 \pm 1.463^{\mathrm{Aa}}$ \\
\hline & Chest depth & $170.852 \pm 1.643^{\mathrm{B}}$ & $172.778 \pm 2.012$ & $176.158 \pm 2.770^{\mathrm{A}}$ \\
\hline & Hip width & $41.481 \pm 0.260$ & $41.306 \pm 0.319^{b}$ & $42.447 \pm 0.439^{\mathrm{a}}$ \\
\hline \multirow[t]{5}{*}{ G18362A } & & GG & GA & AA \\
\hline & Withers height & $126.154 \pm 1.288$ & $127.212 \pm 0.911^{\mathrm{a}}$ & $124.607 \pm 0.555^{b}$ \\
\hline & Body length & $143.038 \pm 1.827$ & $141.635 \pm 1.292$ & $141.493 \pm 0.787$ \\
\hline & Chest depth & $173.769 \pm 3.369$ & $171.808 \pm 2.382$ & $172.386 \pm 1.452$ \\
\hline & Hip width & $41.808 \pm 0.536$ & $41.654 \pm 0.379$ & $41.529 \pm 0.231$ \\
\hline
\end{tabular}

${ }^{\mathrm{a}, \mathrm{b}}$ Means with different superscripts are significantly different at $\mathrm{P}<0.05 .{ }^{\mathrm{A}, \mathrm{B}}$ Means with different superscripts are significantly different at $\mathrm{P}<0.01$.

\section{DISCUSSION}

Tissue distribution analyses in vertebrates have indicated that LPL is expressed ubiquitously in various body tissues, with the highest abundance in heart, adipose tissue, and skeletal muscle (Tan et al., 1977). As one of three members of the TG lipase family, LPL could contribute to the process of TG-rich CMs and VLDLs (Holmes et al., 2011), and in 
the removal of lipoproteins from the circulatory system (Murthy et al., 1996). In adult sheep, Pethick and Dunshea (1993) found that about $55-60 \%$ of the total amount of free fatty acids originate from hydrolysis of circulating triacylglycerols by LPL. Hocquette et al. (1998) demonstrated that transcript LPL levels are positively related to LPL activity in bovine tissues, including muscles and adipose tissue. Because LPL-mediated processing of lipoproteins is so important for plasma lipid metabolism and fuel delivery to tissues (Davies et al., 2012), one would expect that its activity may directly or indirectly affect growth via limitation of the rate of lipolytic processing in mammals. Based on these results, LPL appears to be an important metabolic regulator, especially in ruminant species.

In the present study, according to the $\chi^{2}$ tests, the genotypic distributions of C18341T and G18362A differed significantly from HWE in Jiaxian cattle. There are two main reasons for these results: 1) The analyzed breed did not have a sufficiently large population size, or 2) Jiaxian cattle have experienced high selection pressure. Artificial selection may have eventually led to the loss of certain alleles except the favored ones.

The associations of the three SNPs in the LPL gene with four growth traits were analyzed using DNA samples from 218 Jiaxian cattle. The results suggested that C18341T is associated with withers height, body length, chest depth, and hip width with TT appearing to be the beneficial genotype. G18362A was associated with withers height and GA seemed to be the beneficial genotype. The $\mathrm{C} 18341 \mathrm{~T}$ was located in the intron region and did not change the structure of the encoded proteins, but our results demonstrated that it was still associated with some of the growth traits. Such associations may be the result of linkage disequilibrium between this SNP and other genes on the same chromosome that have a significant effect on the growth traits studied here ( $\mathrm{Li}$ et al., 2013). Another reason may be that mutations within introns could affect both the splice donor site or nearby regions and regulatory motifs within introns (Cao et al., 2013). Importantly, further verifications are needed for understanding the underlying mechanisms.

\section{CONCLUSIONS}

In summary, based on the results obtained from this study, it can be inferred that the mutations of the LPL gene had effects on growth traits in Jiaxian cattle. However, further research is needed to investigate the mechanism and significance of the polymorphisms on growth traits of cattle in different populations and of larger population sizes.

\section{Conflicts of interest}

The authors declare no conflict of interest.

\section{ACKNOWLEDGMENTS}

Research supported by the National "863" Program of China (\#2013AA102505 and \#2011AA100307-02), the National Natural Science Foundation (\#31272411), the National Beef and Yak Industrial Technology System (\#CARS-38), the National Science-Technology Support Plan Projects (\#2012BAD28B04-03), and the Technical Innovation Engineering Project of Shaanxi Province (\#2014KTZB02-02-01). 


\section{REFERENCES}

Botstein D, White RL, Skolnick M and Davis RW (1980). Construction of a genetic linkage map in man using restriction fragment length polymorphisms. Am. J. Hum. Genet. 32: 314-331.

Cao F, Zhang H, Feng J, Gao C, et al. (2013). Association study of three microsatellite polymorphisms located in introns 1, 8, and 9 of DISC1 with schizophrenia in the Chinese Han population. Genet. Test. Mol. Biomarkers 17: 407-411. http://dx.doi.org/10.1089/gtmb.2012.0438

Davies BS, Beigneux AP, Fong LG and Young SG (2012). New wrinkles in lipoprotein lipase biology.Curr. Opin. Lipidol. 23: 35-42. http://dx.doi.org/10.1097/MOL.0b013e32834d0b33

Ding XZ, Liang CN, Guo X, Xing CF, et al. (2012). A novel single nucleotide polymorphism in exon 7 of LPL gene and its association with carcass traits and visceral fat deposition in yak (Bos grunniens) steers. Mol. Biol. Rep. 39: 669-673. http://dx.doi.org/10.1007/s11033-011-0784-4

Gilbert RP, Bailey DR and Shannon NH (1993). Linear body measurements of cattle before and after 20 years of selection for postweaning gain when fed two different diets. J. Anim. Sci. 71: 1712-1720.

Gonzales AM and Orlando RA (2007). Role of adipocyte-derived lipoprotein lipase in adipocyte hypertrophy. Nutr. Metab. 4: 22. http://dx.doi.org/10.1186/1743-7075-4-22

Goodarzi MO, Guo X, Taylor KD, Quiñones MJ, et al. (2004). Lipoprotein lipase is a gene for insulin resistance in Mexican Americans. Diabetes 53: 214-220. http://dx.doi.org/10.2337/diabetes.53.1.214

Gui LS, Zhang YR, Liu GY and Zan LS (2015). Expression of the SIRT2 gene and its relationship with body size traits in Qinchuan cattle (Bos taurus). Int. J. Mol. Sci. 16: 2458-2471. http://dx.doi.org/10.3390/ijms16022458

Hocquette JF, Graulet B and Olivecrona T (1998). Lipoprotein lipase activity and mRNA levels in bovine tissues. Comp. Biochem. Physiol. B Biochem. Mol. Biol. 121: 201-212. http://dx.doi.org/10.1016/S0305-0491(98)10090-1

Holmes RS, Vandeberg JL and Cox LA (2011). Comparative studies of vertebrate lipoprotein lipase: a key enzyme of very low density lipoprotein metabolism. Comp. Biochem. Physiol. Part D Genomics Proteomics 6: 224-234. http:// dx.doi.org/10.1016/j.cbd.2011.04.003

Huang YZ, Wang KY, He H, Shen QW, et al. (2013). Haplotype distribution in the GLI3 gene and their associations with growth traits in cattle. Gene 513: 141-146. http://dx.doi.org/10.1016/j.gene.2012.10.052

Kim JK, Fillmore JJ, Chen Y, Yu C, et al. (2001). Tissue-specific overexpression of lipoprotein lipase causes tissuespecific insulin resistance. Proc. Natl. Acad. Sci. U. S. A. 98: 7522-7527. http://dx.doi.org/10.1073/pnas.121164498

Kolovou GD, Anagnostopoulou KK and Cokkinos DV (2005). Pathophysiology of dyslipidaemia in the metabolic syndrome. Postgrad. Med. J. 81: 358-366. http://dx.doi.org/10.1136/pgmj.2004.025601

Li M, Sun X, Hua L, Lai X, et al. (2013). SIRT1 gene polymorphisms are associated with growth traits in Nanyang cattle. Mol. Cell. Probes 27: 215-220. http://dx.doi.org/10.1016/j.mcp.2013.07.002

McQuaid SE, Hodson L, Neville MJ, Dennis AL, et al. (2011). Downregulation of adipose tissue fatty acid trafficking in obesity: a driver for ectopic fat deposition? Diabetes 60: 47-55. http://dx.doi.org/10.2337/db10-0867

Müllenbach R, Lagoda PJ and Welter C (1989). An efficient salt-chloroform extraction of DNA from blood and tissues. Trends Genet. 5: 391.

Muñoz-Barrios S, Guzmán-Guzmán IP, Muñoz-Valle JF, Salgado-Bernabé AB, et al. (2012). Association of the HindIII and S447X polymorphisms in LPL gene with hypertension and type 2 diabetes in Mexican families. Dis. Markers 33: 313-320. http://dx.doi.org/10.1155/2012/673452

Murthy V, Julien P and Gagne C (1996). Molecular pathobiology of the human lipoprotein lipase gene. Pharmacol. Ther. 70: 101-135. http://dx.doi.org/10.1016/0163-7258(96)00005-8

Nei M and Roychoudhury AK (1974). Sampling variances of heterozygosity and genetic distance. Genetics 76: 379-390.

Oh D, La B, Lee Y, Byun Y, et al. (2013). Identification of novel single nucleotide polymorphisms (SNPs) of the lipoprotein lipase (LPL) gene associated with fatty acid composition in Korean cattle. Mol. Biol. Rep. 40: 3155-3163. http://dx.doi.org/10.1007/s11033-012-2389-y

Pethick DW and Dunshea FR (1993). Fat metabolism and turnover. In: Quantitative aspects of ruminant digestion and metabolism (Forbes JM and France J, eds.). CAB International Press, Wallingford, 291-311.

Swindell SR and Plasterer TN (1997). SEQMAN. Contig assembly. Methods Mol. Biol. 70: 75-89.

Tan MH, Sata T and Havel RJ (1977). The significance of lipoprotein lipase in rat skeletal muscles. J. Lipid Res. 18: 363-370.

Wang H, Astarita G, Taussig MD, Bharadwaj KG, et al. (2011). Deficiency of lipoprotein lipase in neurons modifies the regulation of energy balance and leads to obesity. Cell Metab. 13: 105-113. http://dx.doi.org/10.1016/j.cmet.2010.12.006

Wang XP, Luoreng ZM, Li F, Wang JR, et al. (2012). Genetic polymorphisms of lipoprotein lipase gene and their associations with growth traits in Xiangxi cattle. Mol. Biol. Rep. 39: 10331-10338. http://dx.doi.org/10.1007/s11033-012-1910-7

Xue J, Sun Y, Guo W, Yang Z, et al. (2013). Haplotypes and effects on growth traits of bovine Wnt7a gene in Chinese Qinchuan cattle. Gene 524: 241-245. http://dx.doi.org/10.1016/j.gene.2013.04.013 